\title{
Are Japanese academic earth scientists doing the best for the earth science problems facing Japan?
}

How appropriate are present earth science
education and research in the Japanese public uni-
versity system? Rigidity of the system and lack of a
tradition for interaction of the research capabilities
of the universities with the "real world" of national
and prefecture government and private industry to-
gether are identified as hindrances that prevent the
earth science departments from flexible response to
the major problems directly facing Japan and the
Japanese people.
Many contemporary problems may be identi-
fied within the broad framework of environmental
earth sciences and natural hazards, yet these prob-
lems remain predominantly the domain of the civil
engineer. The future will require a period of critical
review and reassessment of the role and function of
the geoscience departments in Japanese universities
in relation to the aspirations of modern affluent
Japan. This may lead to recognition of the need
for, and calls for, a radical reorganization of the
system.

\section{Introduction}

Compared to many technologically advanced countries in the world, the situation for some areas of the discipline of earth sciences in Japan does not appear to be in good shape in the universities. Why is this? There are clearly many opinions, but we believe two reasons to be of major significance: (1) rigidity of the system and (2) lack of a tradition for interaction between the universities and either government or private industry.

The first reason that earth science departments are not responding to the major problems facing Japan today is that the system in the universities requires rigidly fixed positions. The subdisciplines of earth science each have a staff of three: a professor, an associate professor, and one or two assistants. This means that promotion for excellent performance is not possible until a higher position becomes vacant. Academic staff are on the "escalator system" of salary increases that come with age, not performance, and with secure tenure.

Tenure of appointment is always a thorny issue. Its proponents argue that the security of academic freedom cannot be guaranteed in an atmosphere of anxiety. On the other hand, the damage done to the system by underperforming, even nonperforming, professors may be much worse. Such a situation destroys the morale of free inquiry and intellectual inspiration at all lower levels among colleagues, assistants, and especially students. The problem with secure tenure is that the individual is not accountable for a lack of productivity. Academic productivity is measured primarily through excellence in teaching and research and usually, although not exclusively, through publication. Compared to their counterparts in many Western universities, Japanese academics have extraordinarily light teaching loads in terms of the number of contact hours, the number of courses and lectures, and the laboratories and field trips required. Accordingly, one should expect Japanese professors to have greater research output as a result. On the other hand, Japanese professors generally do not have the secretarial and technical assistance considered to be more cost effective in most Western countries for such things as routine and menial administration and laboratory preparation.

Of prime concern to us here is the rigidity of the Japanese system, which means that the system is locked into the tradition of its establishment. Thus, the existing system is not flexible enough to respond to contemporary problems. For example, our geoscience departments tend to produce graduates who are trained in the traditional core subjects of mineralogy and petrology, paleontology and stratigraphy, and tectonics. Although the study of these subdisciplines is inherently interesting and admirable for general undergraduate education and personal interest, nonetheless one must ask: (1) What are the geoscience needs of modern-day Japan, arguably the most advanced technologically and, collectively, the wealthiest country in the world? (2) How many postgraduate degrees and professional earth scientists does the country really need each year in petrology, paleontology, and tectonics? How many trained hardrock geologists will industry or regional and national government support? And (3) would industry and government support more earth science graduates trained in environmental earth sciences and natural hazards?

Colleagues joke with irony that industry prefers to provide its own tertiary training needs through its own universities. For serious academics, this is a disturbing indictment of the public system.

The second reason we believe that the earth sciences may be inhibited from assuming a higher profile in public perception is twofold, partly an accident of history and partly the result of bureaucratic inflexibilities inherent between different government departments. Individual scientists and institutions within the universities have a certain difficulty and lack of autonomy - not by regulation, but by atmosphere - in negotiating research funding exclusive of the Ministry of Education, Science and Culture (Monbusho) or in undertaking cooperative and contract research with other government departments and the private sector. This is a pity because when little interaction takes place between the universities and the "real world" of either regional and national government or the private sector, university training becomes introspectively and abstractly "academic," even sterile. It lacks the excitement, challenge, and stimulation of "real world" problem solving and application, not to mention the warmth of satisfaction, evident in the engineering profession, that results from positive contributions made from the application of one's research and skills to an earth science problem directly affecting the community. Because universities exist by the support of the community, universities must be able to show a return to the people who ultimately pay for them through their taxes. 


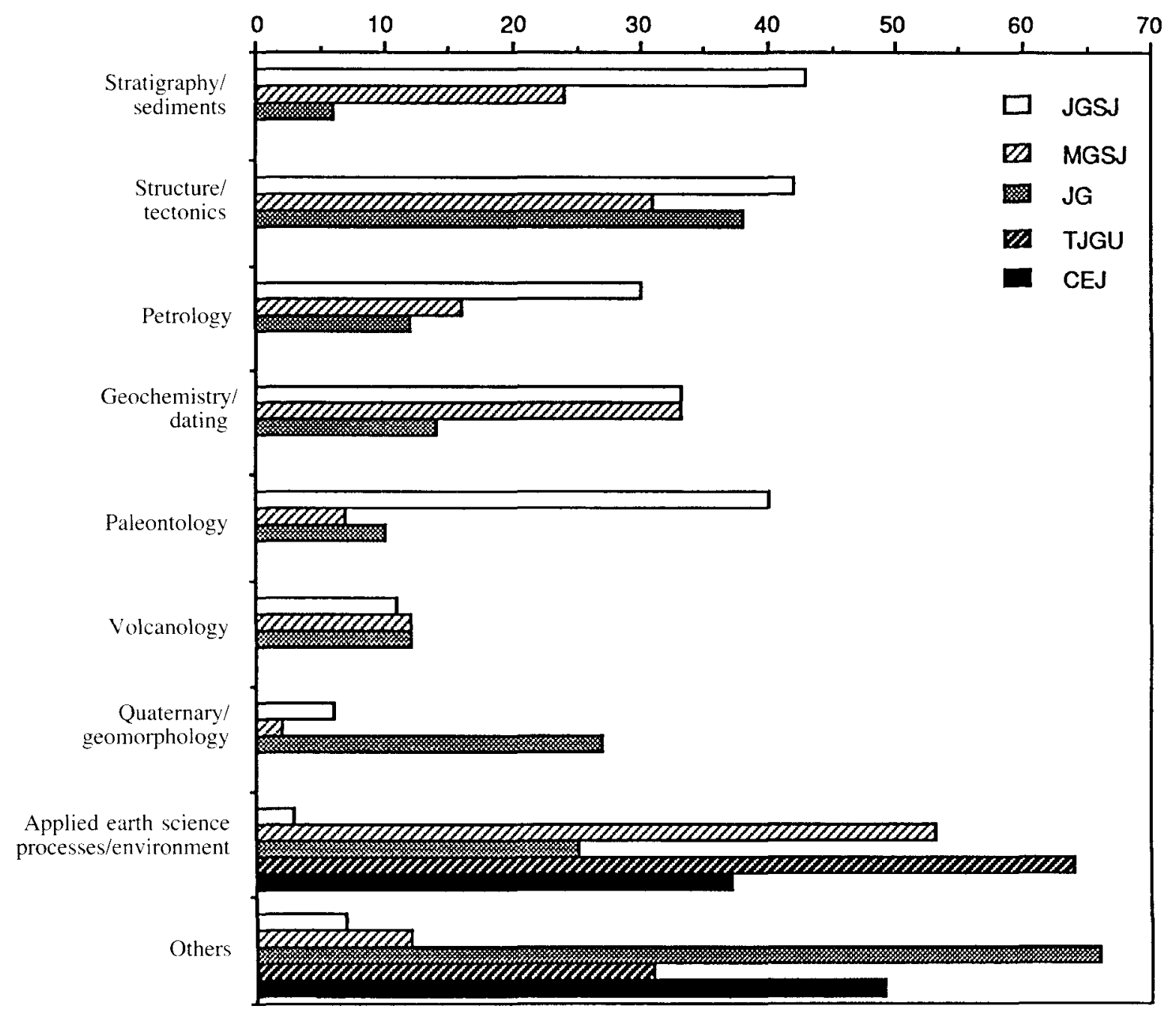

Figure 1._Results of a survey on the types of papers published in some prominent Japanese geoscience journals from 1985 to 1989. Abbreviations: JGSC, Journal of the Geological Society of Japan; MGSJ, Memoirs of the Geological Society of Japan; JG, Journal of Geography; TJGU, Transactions, Japanese Geomorphological Union; and $C E J$, Coastal Engineering in Japan.

\section{Environmental earth sciences-the missing realm}

A major area overlooked by Japanese geoscientists is the field of environmental earth sciences. This area of geoscience broadly encompasses (1) the nature and processes of surficial geology, geomorphology, soil, hydrology and ground water, and the coastal zone; (2) earth science aspects of resource management and pollution problems, such as sand and gravel extraction, pollution from dredge-spoil dumping, sedimentation impacts from highway or port construction. and ground-water contamination and management; and (3) geologic hazards, such as earthquakes, volcanic eruptions. tsunamis, coastal erosion. landslides, and floods.

To illustrate our point, we undertook a survey of the types of papers that appeared from 1985 to 1989 in some prominent Japanese geoscience journals, including particularly the Journal of the Geological Society of Japan, Memoirs of the Geological Society of Japan, the curiously misnamed Journal of Geography, the Transactions of the Japanese Geomorphological Union, and, for comparison. Coastal Engineering in Japan. Results of the survey are presented in figure 1, where papers have been broadly classified into stratigraphy and sediments, structure and tectonics, petrology, geochemistry and dating, paleontology, volcanology, Quaternary and geomorphology, applied earth science processes and environment, and others. The figure demonstrates clearly the predominance of papers on hard-rock geology in the main earth science journals, whereas the geomorphology and engineering journals account for most of the environmental earth science papers. The exception is the Memoirs of the Geological Society of Japan, some issues of which were devoted to special symposiums such as landslides.

Research and recognition for work in the area of environmental earth sciences in Japan is predominantly the domain of the civil engineer. Note, for example, the Ports and Harbours Research Institute at 
Yokosuka and the Disaster Prevention Research Institute at the University of Kyoto, both staffed almost entirely by engineers. Not only is this unfortunate, but it is counterproductive for the image of Japanese earth scientists as well. The people of the community are affected by natural disaster phenomena, predominantly geologic in character, and yet they associate the study. mitigation, and solution of the phenomena with the role of the civil engineer. Clearly, the earth scientist tends to view such phenomena in a different way and can contribute an alternative perspective to the understanding and mitigation of such natural phenomena (Healy, 1980; Ikeda, 1985). For example, the marine geoscientist and the coastal engineer study much in common on beach behavior, wave theory, and currents. However, the engineer is not equipped to investigate the origin of the beach sands by analyzing the mineralogy, and particularly the petrology, of the heavy minerals. Likewise, the geoscientist is not trained to design structures for containing a beach but is, nevertheless, able to provide critical assessment on how well the structures perform their function. Similarly, the engineer may study slope failures, perform geomechanics and ground-water tests, and design stabilizing walls. The earth scientist likewise may undertake groundwater and geochemical analyses but can study the clay mineralogy and petrological fabric of the rock as well, thereby enhancing understanding of the basic cause of rock failure. In the case of underground nuclear waste disposal (Koide, 1987), the engineer can design the containment structures, but the geologist needs to contribute the long-term prediction of geologic stability or instability of the site.

\section{Increasingly on the world scale, a multidisciplinary approach to environmental problems is recognized as necessary, but for Japan, a major problem is the lack of this approach.}

When problems are perceived to be the domain of one dominant discipline, the great danger is that a "we-know-best" attitude tends to develop. But in the field of engineering, which deals primarily with surficial geologic phenomena and processes, many engineers now recognize that their knowledge is far from perfect and that nonengineers may make significant contributions. Note, for example, the close mix of engineers and scientists at meetings run under the auspices of the American Society of Civil Engineers, such as Coastal Sediments '87, Coastal Zone '89, and the International Conferences on Coastal Engineering. Paralleling this has been the employment of significant numbers of professional scientists within the U.S. Army Corps of Engineers. Also in the United States, the multidisciplinary U.S. Environmental Protection Agency provides an environmental safety buffer against excesses from engineers, industry, and developers.

Even in Japan, some engineers recognize the contribution that is possible from geoscientists (Ikeda, 1985; Okimura, 1989). Some years ago, Okusa (1986), a marine geotechnical engineer, noted the contribution of the geosciences to marine geotechnology in foreign countries, and he called for interdisciplinary collaboration in Japan. Likewise. Aoki (1985) noted that "in the near future, collaborative study would become necessary as an interdisciplinary branch for nat ural disaster researches." But there is little evidence in the Japanese geoscience literature that these calls have been accepted and acted upon.

\section{Monodisciplinary versus multidisciplinary approaches to environmental impact assessment and natural hazards}

Increasingly on the world scale, a multidisciplinary approach to en vironmental problems is recognized as necessary, but for Japan. a major problem is the lack of this approach. Probably this tradition can be traced back to the post-World War II era. when the essential aims were to get the country and economy back on its feet. Environmental considerations for large-scale developments were of secondary importance.

Is Japan's traditional monodisciplinary approach appropriate today? In many countries, problems such as water resources analysis and management or coastal management involve research and decision making by a team that incorporates both scientific and engineering expertise. And the scientific expertise includes a broad spectrum of interdisciplinary fields, often involving planners, geographers. ecologists, microbiologists. and geochemists, as well as earth scientists and hydrologists or oceanographers. A good example is the international, multidisciplinary approach that is being applied today to problems of coastal erosion and management of the European coast of the North Sea.

The pertinent question to be asked for Japan is whether the present system of essentially a single disciplinary approach gives the Japanese people and communities the best solution to environmental problems and to the management of the national public assets. such as ports, harbors, beaches, the coastal zone, rivers, water resources. and especially ground water.

Clearly, the prevailing view from many countries in the world is that a multidisciplinary approach is superior for long-term solutions to such problems. Some evidence suggests that this feeling is starting to be realized in Japan. Suzuki (1989), reviewing the contribution of Japanese geomorphologists, rather tentatively noted the need for a "good environment for promoting the cooperation between geomorphologists and related scientists and engineers," and that such progress may be useful "for providing a basis for the solution of practical problems such as disaster prevention and better land use." In a like vein, Ikeda and Ouchi (1989) commented on the tendency toward interdisciplinary work that is growing among workers studying fluvial processes and landforms. They expect this trend to exert significant effects on the progress of the discipline.

More engineers, too, are starting to see the value of the interaction between geoscience and engineering. Okimura (1989) perceptively concluded: "As studies of man-made landforms have increased in the field of geomorphology, interdisciplinary studies between geomorphology and civil engineering are regarded as an important [step] for ensuring environmental protection."

\section{What can be done for the future?}

Accepting that the present system had its origin in the post-World War II days of occupation, it is timely to raise the question about what can be done for the future.

As a first step, it is certainly appropriate for Japanese academi earth scientists to impose some deep self-examination. Do they wish to play a more active role in the wider spectrum of earth science problems facing the Japanese people as a whole? Such involvement would make their products, the graduate students and their research results, a more marketable, useful. and self-satisfying product. Thesu changes can be initiated by both individuals and departments within the present system. 
Other problems raised in this paper will require some structural change to the system. It should not prove too difficult to grant greater autonomy to universities and departments for negotiating and actively seeking greater participation in earth science environmental problems at various levels of national and prefecture government. However, the problems associated with the rigidity of the system clearly will require massive review and rationalization.

\section{The earth scientists in Japan largely have abrogated their expertise and responsibilities in the field of environmental problems and natural hazards and have left them to the domain of the civil engineer.}

\section{Is structural change possible?}

For those professors of earth science who are comfortably skeptical that structural change to the system is impossible, we remind them of the structural review undertaken in The Netherlands in recent years. There, geoscience departments from several universities were "rationalized" and amalgamated so that only two now remain (Free University and Utrecht). The basis of the rationalization was the question: why does a small country like The Netherlands need to produce a group of research geologists when the geology of the country is essentially quite simple and already well known? Such a question also may need to be faced by the academic geologists in Japan in the future.

Similar review and rationalizations took place in recent years in British university geoscience departments (Okada, 1989), as well as in the Soil Survey and the Institute of Oceanographic Sciences. In Australia and New Zealand, tertiary geoscience education is undergoing review and reorganization (Carter, 1988). Although such reorganizations may have dire personal consequences for some individuals, its proponents claim that the system remains more vital and responsive to the needs of a constantly evolving and complex modern society.

Of course, some perceive the danger that the science might become entirely applied in nature. This is not the experience of the senior author, who has negotiated and undertaken large numbers of contract research projects supporting students working for master's and doctor's degrees in a Western country. To those of us who have done contract research, it is clear that, in reality, applied science is 95 percent basic research. The "art" is to set up the research framework in such a way that the results are of some direct application to the sponsor of the research, just as the Nearshore Environmental Research program (NERC) was established (with participation entirely by engineers) to undertake essentially fundamental research into beach behavior for the ultimate benefit of the electric power industry of Japan (Horikawa, 1988). This program has produced major advances in the understanding of beach processes in Japan.

\section{Conclusions}

From our review, the following points are pertinent.

(1) The earth scientists in Japan largely have abrogated their expertise and responsibilities in the field of environmental problems and natural hazards and have left them to the domain of the civil engineer.

(2) This approach relegates the earth sciences in Japan to a low profile in the public recognition, which results in decline in popular perception and relative funding support for the discipline.

(3) The essential issue is to determine the crucial earth science problems facing Japan and the Japanese people. Consideration of this issue cannot fail to recognize that many more people are affected directly by environmental and natural hazard problems than by problems arising, for example, from mineralogy or microfossils.

(4) Accordingly, the academic earth scientists need to undertake a fundamental self-reexamination to decide whether they are really providing answers to the most urgent earth science and natural hazard problems facing the Japanese people.

(5) The earth scientists and the entire university system also need to address the question as to whether it is time to review the university system fundamentally. In particular, they need to assess whether greater productivity, greater accountability, and reward for excellence are appropriate for Japanese academics.

\section{Acknowledgment}

This paper was written while the senior author was on research leave from the University of Waikato. Support in the form of a Senior Research Fellowship from the Japan Society for Promotion of Science held at the Department of Earth Sciences, Yamagata University, is gratefully acknowledged.

\section{References}

Aoki, Shigeru, 1985, Natural disaster researches by Japanese geologistsPast, present and future: Memoirs of the Geological Society of Japan, v. 25 . p. $453-463$

Carter, R.M., ed., 1988, The place of geoscience in Australian education: James Cook University of North Queensland, Economic Geology Research Unit, Contribution 28, $68 \mathrm{p}$.

Healy, T.R., 1980, Conservation and management of coastal resources -The earth science basis, in Anderson, A.G., ed., The land our future, essays on land use and conservation in New Zealand: Auckland, Longman Paul, p. $239-260$

Horikawa, Kiyoshi, ed., 1988, Nearshore dynamics and coastal processes: Tokyo, University of Tokyo Press, $522 \mathrm{p}$.

Ikeda, H., and Ouchi, S., 1989, Fluvial processes and landforms: Transactions, Japanese Geomorphological Union, v. 10A, p. 47-56

Ikeda, T., 1985, Significance of geomorphological observation and interpretation for civil engineering projects: Transactions, Japanese Geomorphological Union, v. 6. p. 153-162.

Koide, H., 1987. Geological disposal of high level radioactive wastes in Japan and earth sciences: Journal of Geography (Japan), v. 96, no. 3, p. $144-155$ 
Jkada, H., 1989, Reorganization of university geology departments of Great Britain: Journal of the Geological Society of Japan, v. 95, no. 2, p. 152-153.

Okimura, T., 1989, Man-made landform transformation: Transactions, Japanese Geomorphological Union, v. 10A, p. 139-145.

Okusa, S.. 1986, Marine geotechnology: A new interdisciplinary branch of science and technology: Journal of the Geological Society of Japan, v. 92, no. 12 , p. 879-903.

Suzuki, T., 1989, Hierarchy of geomorphological understanding and the recent status in Japan: Transactions, Japanese Geomorphological Union, v. $10 \mathrm{~A}$, p. $1-12$.

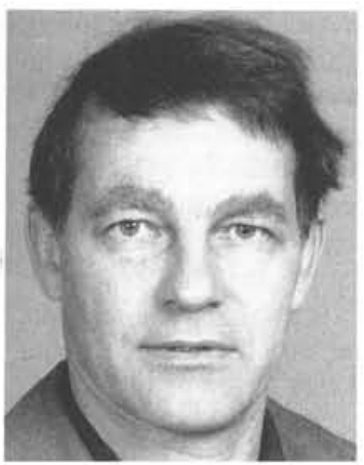

Dr. Terry Healy, appointed to the faculty at the University of New South Wales in 1970, moved to Waikato University in 1973. Research areas include coastal erosion, inlet and inner shelf sedimentation and their application to planning and development, marine geology and oceanography, climatic change impacts, and fluvial sedimentation. Particularly active in applied research, he presently supervises some 16 postgraduate students, mostly on funded contracts. He was awarded an Alexander von Humboldt Research Fellowship (1978, 1985, 1989), held at the University of Kiel, FRG, and a Japan Society for Promotion of Science Research Fellowship (1989), held at Yamagata University. He is Associate Editor for marine geology for the Journal of Coastal Research.

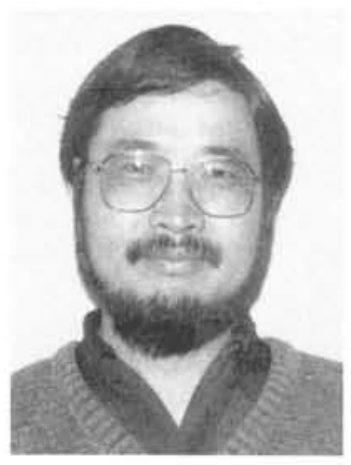

Dr. Kenichi Harada graduated from the Department of Geology and Mineralogy, Kyoto University, Japan, in 1970 and obtained his doctorate from the same department in 1977 by doing biostratigraphic work on deep-sea manganese nodules. From 1978 to 1979, he studied at the Geological and Paleontological Institute, University of Kiel, FGR, as a Research Fellow of the Alexander von Humboldt Foundation. From 1979 to 1980, he was a Visiting Lecturer at the Department of Geology, Washington State University at Pullman, Washington, USA. Recently, he has devoted himself to the comparative study of Japanese and world civilizations in terms of their geologic settings, such as land properties, underground resources, tectonic movements, and geomorphology. 